affected youth. His project won the Lancet Outstanding Global Health Research Award in addition to several poster prizes. He also worked as a humanitarian health consultant for UNICEF and the Norwegian Refugee Council addressing issues of shelter, child protection, and population movement.

His vision of his future career involves grappling with health policy issues and innovating community based care models that empower patients to be proactive and preventive in their health care.

Mark Stoltenberg, a 2010 Pisacano Scholar, is a 4thyear medical student at Loyola University Chicago Stritch School of Medicine, where he also received a Dean's scholarship to complete his master's in bioethics and health policy. He graduated from Duke University with a Bachelor of Arts in Religion. From the age of 13 through college, he volunteered at a children's hospital. During his senior year, he participated in service trips to Salem, West Virginia, and Managua, Nicaragua, both poverty-stricken areas.

During his first 2 years of medical school, Mark created a family advocacy program that connects local underserved families with medical students through a new service-learning curriculum. Mark and a few of his classmates chose to move into the underserved community and develop a survey-based research study in conjunction with the department of preventive medicine to better assess the community of Maywood. With his research, Mark hopes to give the department a better understanding of the local community that will more accurately direct future projects and initiatives.

As an Albert Schweitzer fellow, Mark recently began a self-designed, year-long fellowship. This fellowship will allow Mark to commit a year to act as the medical coordinator for a 13 -village clinic system in rural Bolivia which was started by a Loyola attending physician and her husband 9 years ago. During his year there, Mark will be coordinating the public health projects conducted by the clinic, fostering communication between the clinic and the 13 villages it serves, and also assisting in patient care alongside visiting attending physicians. Once instituted, Mark plans to make his position a permanent Global Health Fellowship.

Mark plans to remain in academic medicine and continue working with the various projects and communities he has connected with while in medical school.

Jane Ireland

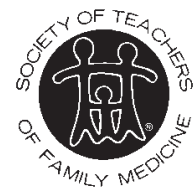

From the Society of Teachers of Family Medicine

Ann Fam Med 2010;8:567-568. doi:10.1370/afm.1208.

\section{EMERGING LEADERS PROGRAM}

STFM is excited to launch their Emerging Leaders program. Applications are now being accepted for the first "class" of fellows.

\section{Components of the Emerging Leaders Program} The Workshop

The leadership program experience will begin at an Annual Spring Conference workshop, where participants will learn about leadership, with emphasis on the self-reflection and self-awareness skills required of a good leader. Stephen Bogdewic, PhD, will be teaching this workshop. His material is based on the popular leadership book, The Leadership Challenge, by James M. Kouzes and Barry Z. Posner.

The Leadership Project

All participants in the Emerging Leader Fellowship will complete a project that will involve leading a group to complete a task or initiative for STFM. These tasks/ initiatives will come from STFM Groups and Committees. This experience of actually leading an effort is part of what makes this leadership program unique.

Leadership Circles

Participants will discuss their project in Leadership Circles, quarterly conference calls with their peers and a facilitator. The leadership circles will be facilitated by STFM members who are behavioral scientists.

\section{Coaches}

The participants will also get advice and feedback from their coach as they work on the project. The coach will be responsible for moving the participant along and helping them lead toward completion.

\section{Mid-Year Meeting}

The participants will meet at the AAFP's National Conference in the summer for a mid-year meeting, which will build upon the content and experience of the workshop and leadership circles.

\section{Presentations \& Wrap-Up Meeting}

The participants will be involved in a wrap-up and "review" session at the Annual Spring Conference at 
the end of their experience. At the end of the Fellowship experience, participants will present their project in a poster at the STFM Annual Meeting. Additionally, they will give a short presentation ( 5 minutes) to the STFM Leadership. This presentation will add a certain prestige to the program but will also allow STFM Board Members and leaders to identify "up and comers" and perhaps get them involved in projects or committees.

\section{What's Different About This Leadership Program?} Why Should I Participate?

STFM's program is designed specifically for family medicine educators. If you love family medicine, and you love teaching, then this program will teach you how to become a leader.

You will be in a leadership role when you arrive to start the program, right from the beginning.

You will learn many things, from many people, many ways (coaches, faculty, workshop), but this program starts you with actual experience selecting talent, chairing conference calls, motivating others, and leading.

If I'm Actually Leading a Group, What Will I Do if I Have Obstacles (or a Difficult Team Member)? That's how your coach will be helpful. You'll have the ear of someone who's an accomplished leader (an STFM Winston Churchill, if you will). Your coach can tell you how to handle difficult people, difficult situations, and share secrets of motivating others. You can ask them anything, and they will set you up for success.

You can also take advantage of the "Leadership Circles." On these conference calls, you will learn new leadership topics, but can also cuss-and-discuss problems among the other participants, hear of other's lessons, and share tips and tricks for leading your group to success.

\section{Why Should I choose This Program Over Other} Options for Presenting?

Visibility. You'll present your work (and yourself) to the STFM leadership — the people who are incredible connections and may appoint you to a leadership role within STFM or another organization.

You'll attend the STFM Annual Spring Conference 2 years in a row. Nothing tops this conference for networking, exposure, and presentation experience.

\section{A Sample Year For a Participant in Emerging Leaders}

- March: Notification of acceptance in the program

- Selection of the project and team to be led

- April: Attendance at the STFM Annual Spring Conference

- Welcome reception with the faculty, participants and coaches
- Pre-conference workshop on leadership

- Meet your coach

- Summer \& Fall: Lead your group to completion of the project. Get periodic feedback and advice from your coach.

- Participate in quarterly "Leadership Circles" conference calls

- Early August: Attend a mid-year meeting (to be held in conjunction with the AAFP's National Conference)

- Spring: Prepare your presentations

- April: Present your poster at the STFM Annual Spring Conference

- Present a brief oral report of your project to the STFM Board of Directors

- Attend additional leadership programming.

- Apply for Emerging Leaders at STFM.org/ EmergingLeaders

Angela Broderick, MA, CAE

Deputy Executive Director, STFM

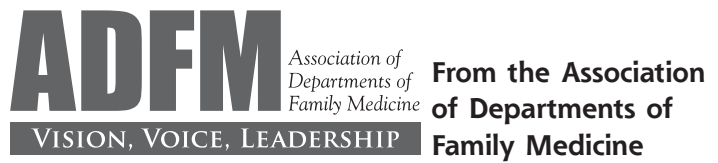

Ann Fam Med 2010;8:568-569. doi:10.1370/afm.1205.

\section{HEALTH REFORM, ACADEMIC HEALTH CENTERS, AND FAMILY MEDICINE}

The Patient Protection and Affordable Care Act (PPACA) was signed into law on March 23, 2010. In addition to expanding health insurance coverage to an estimated 32 million individuals by 2019, the bill has myriad components that will have widespread effects on the health care system. ${ }^{1}$ Academic health centers (AHCs) will be among the many institutions touched by the reforms enacted by the PPACA. Will these reforms be powerful enough to shake AHCs out of their traditional business model of delivering highly specialized services to become more integrated, patient-centered delivery systems?

The PPACA will challenge the way hospitals do business. By 2014, hospitals will experience a cut in Medicaid and Medicare Disproportionate Share payments of $\$ 14 \mathrm{~B}$ and $\$ 22.1 \mathrm{~B}$, respectively-and these cuts will fall disproportionately on teaching hospitals. Some of the cuts will be offset by decreases in uncompensated care liabilities as fewer patients are uninsured. A more fundamental challenge will come from the pressures on AHCs to become Accountable Care 